\title{
EFFECT OF IN-OVO INJECTION OF TESTOSTERONE ON HATCHABILITY AND PLASMA CONSTITUENTS IN DOKKI-4 CHICKENS
}

\author{
Hanaa M. Hussin, Nematallah G. Mohammed, Badri F.B.A. and Maie F. Ali \\ Poultry Production Dept., Fac. of Agric., Ain Shams Univ., P.O Box 68, Hadayek Shobra \\ 11241, Cairo, Egypt \\ *Corresponding author: faisalbadri@agr.asu.edu.eg
}

$[172]$

Accepted 26 May, 2018

\section{ABSTRACT}

This study was designed to evaluate the effects of testosterone propionate (TP) on hatchability, chick measurements and some plasma metabolites in Dokki- 4 strain of chickens during embryogenesis stage. A total of 350 fertile eggs (45-55 g. in average) were individually weighed and incubated .At the $5^{\text {th }}$ day of incubation، eggs were divided into 3 experimental groups as follow; control(C) non-injected groups, while the other groups $\mathrm{T} 1$ and T2 eggs were injected in albumin with 25 and $100 \mu \mathrm{g}$ TP solvated in $50 \mu$ l plant oil.

Results showed that hatchability \% was significantly decreased in-ovo injected groups by 12 $14 \%$ than control groups, while embryonic mortality rate was increased by in-ovo injection with TP. Chick weight, total protein, albumin, calcium and phosphorus levels were significantly increased in TP injection than control .Also, male chicks \% based on the visual examination was increased by TP in -ovo injection than control.

In conclusion: in-ovo injection of TP at the $5^{\text {th }}$ day of incubation with 25 and $100 \mu \mathrm{g} T \mathrm{~T} / 50 \mu \mathrm{l}$ plant oil had decreased the hatchability $\%$, but increased embryonic mortality, some plasma constituents, male\% ,chick weight and chick length in Dokki-4 strain of chickens.

Keywords: Testosterone, In-ovo injection, Hatchability, Dokki- 4 Chickens.

\section{INTRODUCTION}

The sex hormones are involved in many important physiological and biological processes. These biological processes are of considerable import to those interested in the broiler production because there is less benefit of females as for males due to their lower body weights. Whiting and Pesti (1983) reported that one -day old male chicks were heavier than females. Also, Burke and Sharp (1989), Burke et al (1990) and Burke (1992) observed a difference in body weights between male and female at hatching. They added that male chicken embryos were significantly heavier than female. Over the last fifteen years, there has been an increased interest in ovo injection with natural male hormone testosterone or synthetic anti-estrogen aromatase inhibitors, in their effects on sex differentiation of the embryonic chick weight. This difference in body weight was detected in both the embryonic and post hatch period. Sexual differentiation may depend upon genetic cell autosomons and hormonal mechanisms.

The effect of in ovo injection of gonadal hormones on sex differentiation is affected by a number of factors including time, dose, site of injection and type of solvent of hormones. Even if these factors were held constant, still the kind of hormone injected affects the result of sex differentiation. Sex differentiation in chicken is first visible in male or female histologically from day 6 (stage 29) Hamburger and Hamilton (1951, 1992).

From other points, Bruggeman et al (2002) observed that in ovo injection of aromatase inhibitors either steroidal or non-steroidal resulted in masculinizing of genetic female. Also, Vaillant et al $(2001,2003)$ reported that, one $\mathrm{mg}$ fadrozole (non-steroidal anti-estrogen) was injected in albumen of chicken eggs at 4th day of incubation. This dose was efficient in inducing phenotypic inversion of sex female to male without affecting survival of the embryos or hatchability. 
Recently, Major and Smith, (2016) suggested a significant role of sex hormones in regulating sexual differentiation and gonadal tissues during embryonic development. Genes involved in gonadal sex differentiation become active during embryogenesis sexually dimorphic gene expression in chicken blastoderm of early embryos. Details of the mechanism or the factors responsible for sex difference in body weight and muscle mass between male and female chickens remain unknown, (Henry and Burke,(1999).

Therefore, the objective of this study was to determine the effects of in ovo injection of testosterone hormone and a natural aromatase inhibitor (garlic) in masculinizing embryonic females into phenotypic males and its effect on body weights and hatchability of Dokki ${ }_{4}$ chicks.

\section{MATERIALS AND METHODS}

The present study was carried out at the poultry research unit, Faculty of Agriculture, Ain Shams University, Shubra El-Kheima, El-Kalyobea Governorate, Egypt. The experiment was lasted for two months, started December 2016 and ended January 2017.

\section{Eggs and incubation}

A total number of 350 fertile eggs from Dokki 4strain (sex linked cross, Barred Plymouth Rock female mated to Fayoumi male) were purchased from El takamoly project, Fayoum Governorate, Egypt. The eggs were individually weighed before incubation, their weights ranged from (44.5 to 54.5). Eggs were set in incubator at $99.8^{\circ} \mathrm{F}$ and $65 \%$ relative humidity, turned automatically every 2 hours for 18 days, and then transported to hatcher basket with 99.7 $\%$ and $75-80 \% \mathrm{RH}$. At the $5^{\text {th }}$ day of incubation, eggs were candled and the infertile eggs were discarded and taken out of the incubator.

\section{Experimental treatments}

The eggs were divided into 3 experimental groups, $1^{\text {st }}$ group was control without any treatment, while $2^{\text {nd }}$ and $3^{\text {rd }}$ groups were injected with 25 and $100 \mu \mathrm{g}$ testosterone propionate dissolved in plant oil, respectively.

\section{Injection procedure}

At the $5^{\text {th }}$ day of incubation, the eggs were sterilized with $70 \%$ ethyl alcohol and pierced at small end using a $1 \mathrm{ml}^{3}$ syringe with a 23-gauge needle. Testosterone solutions were injected into the albumin fluid (matrix). Sterile shell hole was sealed with glue stick and adhesive tape and then eggs were returned to the incubator, immediately.

At the $18^{\text {th }}$ day of incubation, eggs were taken out of the incubator, weighted individually and their weights were recorded and the egg weight loss \% was estimated according to the following equation:

$$
\text { Egg weight loss } \%=\frac{\text { Egg wt. at the begining of incubation }- \text { Egg wt at } 18 \text { days of incubation }}{\text { Egg wt.at the begining of incubation }} 100
$$

\section{Hatchability percentage}

The eggs that were apparently having live embryos were set in hatching baskets at $99.8^{\circ} \mathrm{F}$ and a range of 75 to $85 \% \mathrm{RH} \%$ for the last three days of incubation. At $21^{\text {st }}$ day of incubation chicks that hatched, were individually weighed and their weights were recorded. Chick wt.to egg wt., egg shell wt. to egg wt. and hatchability percentages calculated.

\section{Embryonic mortality}

On day 22 of incubation, Breakout analysis for unhatched eggs for each treatment groups were done and embryonic mortality was calculated during early and late stages.
Hatchability and embryonic mortality percentages were calculated based on the number of the fertile eggs.

\section{Sex determination of hatched chicks}

Sex determination of chicks was determined by visual examination where Dokki -4 strain is sexually dimorphic. Females have black head, while males have a white spot on their head and the sex ratio was calculated based on the visual examination.

\section{Chick quality traits}

At hatch, 6 chicks per treatment were taken ( 3 females and 3 males based on visual examina- 
tion). Shank length (SL) was measured from the hock joint to the tarsometarsus digit using digital caliber (mm). Body length (BL) was measured from the base of the neck to the base of the tail around the uropygial gland, using ruler (centimeter).

\section{Blood samples collecting}

At hatch, five chicks from each treatment were randomly taken and blood samples were obtained by heart puncture procedure $\left(0.3 \mathrm{ml}^{3} /\right.$ chick $)$, in heparinized tubes then centrifuged at 4000 RPM for 15 minutes and plasma samples were decanted in Eppendorf tubes and stored at $-20^{\circ} \mathrm{C}$ until the biochemical analyses were done.

\section{Plasma biochemical parameters}

Plasma concentrations of total protein $(\mathrm{g} / \mathrm{dl})$ were obtained according to the method described by Henry (1974). The determination of plasma albumen $(\mathrm{g} / \mathrm{dl})$ based on a colorimetric method described by Doumas and Biggs (1972). Globulin was calculated by subtracting albumin from total plasma proteins for each sample. Cholesterol $(\mathrm{mg} / \mathrm{dl})$ were determined according to the method of Richmond (1973). Triglycerides (mg/dl) were determined by the method of Stein and Myers (1995). Alkaline phosphatase (ALP) level was determined based on the colorimetric method described by Tietz (1976) Plasma phosphorus and calcium (mg/dl) was determined by using a commercial kits.

Statistical analysis: The obtained data from the present study were processed and analyzed with the Statistical Analysis Software ${ }^{\circledR}$; Release 6.12 SAS (1998) .The model of one-way analysis of variance was used for Hatchability \%, Male \%, chick body weight, some egg parameters and plasma biochemical parameters. The model was used as follows:

$$
Y_{i j}=\mu+T_{i}+E_{i j}
$$

Where:

$\mu=$ effect of overall mean.

$\mathrm{T}_{i}=$ effect of $\mathrm{I}$ treatment

$\mathrm{Eij}=$ random error.

The model of two-way analysis of variance with interaction was applied with body and shank length. The model was used as follows:

$$
Y_{i j k}=\mu+T_{i}+S_{j}+T_{i} S_{J}+E_{i j k}
$$

\section{Where:}

$\mu=$ effect of overall mean.

$\mathrm{T}_{i}=$ effect of $\mathrm{I}$ treatment.

$\mathrm{S}_{\mathrm{j}}=$ effect of the $\mathrm{J}$ sex.

$\mathrm{T}_{\mathrm{i}} \mathrm{S}_{\mathrm{j}}=$ the interaction between $\mathrm{I}$ treatment and $\mathrm{J}$ sex.

Eijk $=$ random error

Means were separated according to Duncan (1955) multiple range test when the main effect was significant.

\section{RESULTS AND DISCUSSION}

\section{Effect of in ovo injection of testosterone on hatchability \% and embryonic mortality}

The effect of in ovo injection of testosterone propionate at 25 and $100 \mu \mathrm{g} / 50 \mu \mathrm{l}$ on the hatchability and embryonic mortality\% during the incubation period was illustrated in Fig. (1). It is well noted that, the hatchability \% was significantly decreased (76 and $74 \%$ ), while embryonic mortality rate was significantly increased (21 and $27 \%$ ) in ovo injected groups with 25 or $100 \mu \mathrm{g} / 50 \mu \mathrm{l}$ plant oil respectively, compared with $88 \%$ hatchability and $4.5 \%$ embryonic mortality, hatchability and embryonic mortality rate was related to testosterone injected dose. This was in agreement with the finding observed by (Major and Smith, 2016). However, the hatchability recorded by other investigators indicated thane was either unaffected or was reduced by in ovo injection (Borji and Komazani, 2014).

\section{Chick weight and Chick weight\% of egg weight}

The effect of in ovo injection of testosterone propionate on the body weight of the hatchling was the main objective of the current study. It is clearly noted that testosterone propionate injection at 25 and $100 \mu \mathrm{g}$ levels in $50 \mu \mathrm{l}$ plant oil increased chick weight and chick /egg weight \% at hatch compared with non-injected (control) group (Table 1). These results are in agreement with (Burke, (1992) who reported that testosterone, the natural male hormone, increased skeletal muscle anabolism, while estrogen, the female hormone, enhanced skeletal muscle catabolism. Besides, Henry and Burke (1998) suggested that the muscles of male embryos have more but smaller, myofibres than females, which may be responsible for the sex difference in embryo weight and provide the framework for the greater post hatching muscle growth. 


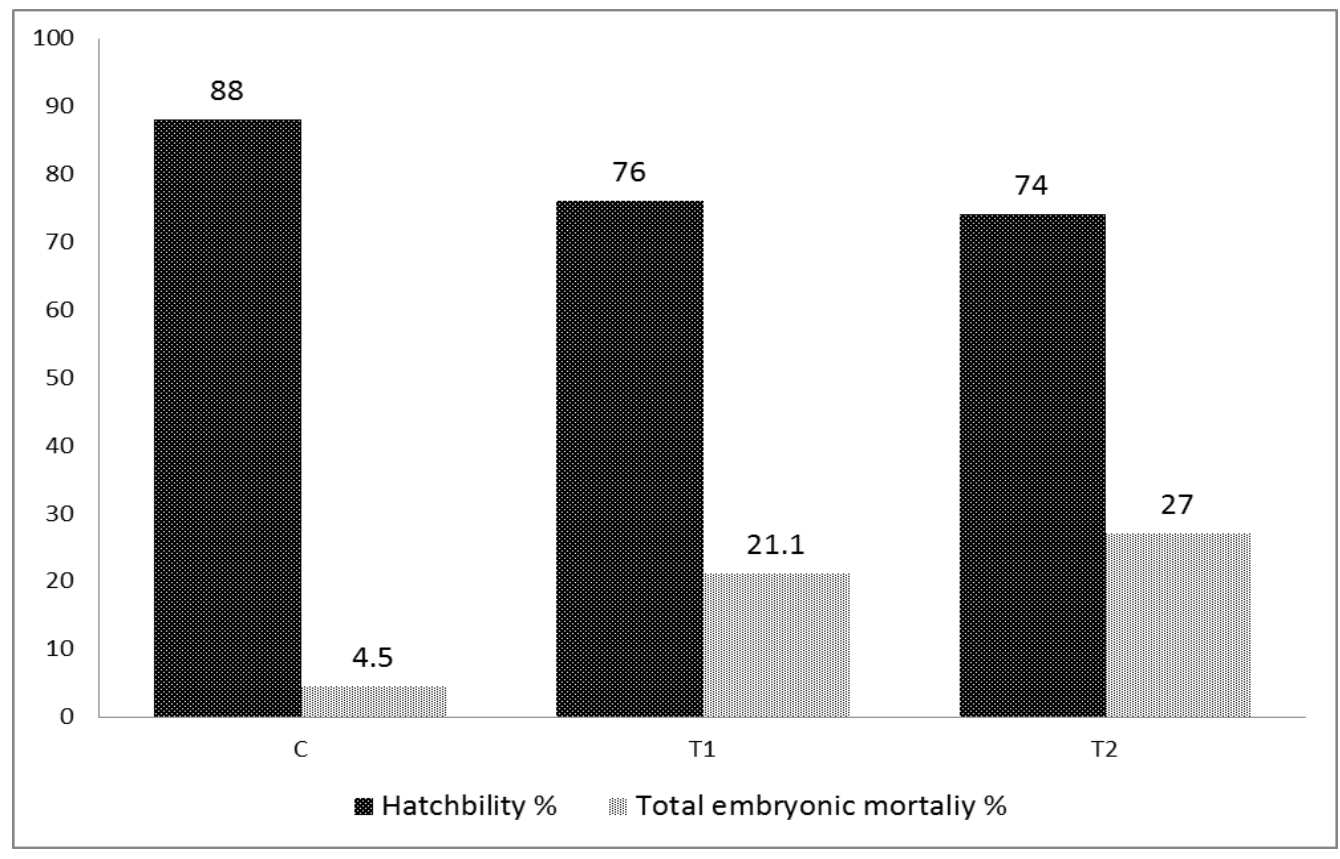

Fig. 1. Effect of in ovo injection of testosterone on the hatchability and total embryonic mortality \% during the incubation period

Table 1. Effect of in ovo injection with and Testosterone propionate on egg weight at zero and18 days, \% water loss, \% chick wt., \% chick/egg wt., \% shell weight of Dokki- 4 eggs in experimental groups

\begin{tabular}{|c|c|c|c|c|c|c|}
\hline \multirow{3}{*}{ Traits } & \multicolumn{3}{|c|}{ Treatments } & \multirow{3}{*}{ SEM } & \multirow{3}{*}{$P$ value } & \multirow{3}{*}{ Sig. } \\
\hline & \multirow[b]{2}{*}{ Control } & \multicolumn{2}{|c|}{ Testosterone } & & & \\
\hline & & $\begin{array}{c}\mathrm{T} 1 \\
25 \mu \mathrm{g}\end{array}$ & $\begin{array}{c}\mathrm{T} 2 \\
100 \mu \mathrm{g} \\
\end{array}$ & & & \\
\hline Egg weight at zero day & 49.54 & 49.31 & 49.40 & 6.74 & 0.89 & NS \\
\hline Egg weight at 18 day & 45.91 & 45.88 & 45.91 & 6.37 & 0.60 & NS \\
\hline Egg weight loss\% & 7.46 & 7.65 & 6.99 & 9.50 & 0.92 & NS \\
\hline Hatchling weight (g) & $32.86^{\mathrm{b}}$ & $34.54^{\mathrm{a}}$ & $34.55^{\mathrm{a}}$ & 6.00 & 0.01 & * \\
\hline chick /egg weight \% & $66.15^{\mathrm{b}}$ & $69.04^{\mathrm{a}}$ & $69.70^{\mathrm{a}}$ & 14.76 & 0.002 & $* *$ \\
\hline Shell weight \% & 9.99 & 10.34 & 10.59 & 27.05 & 0.37 & NS \\
\hline
\end{tabular}

SEM=Standard error of means.

a, b, c; means in the same Column within each classification bearing different letters are significantly different. sig. =Significance

NS=non-significant, ${ }^{*}=(P \leq 0.05),{ }^{* *}=(P \leq 0.01)$. 


\section{3- Egg weight loss $\%$}

The values of egg weight loss \% resulted in in ovo injection of testosterone were not significantly different from control. Similar results were recorded for shell weight \% of egg weight. These results revealed that in ovo injection of testosterone had not any effects on egg weight loss \% or the percentage of egg shell weight.

\section{Effect of in ovo injection of testosterone on chick and Shank lengths at hatch.}

Data presents in Table (2) showed the chick sexing according to the visual examination, the overall mean of chick length and shank length in ovo injected groups were significantly increased in testosterone -injected groups compared with noninjected (control) groups. In ovo injection with $25 \mu \mathrm{g}$ testosterone was more effective than $100 \mu \mathrm{g}$ testosterone in chick length. Generally, male chick was significantly increased in chick and shank length than female. The present results disagreed with those of (Fennel and Scanes, (1992) and (Rath, et al 1996) who studied the effects of testosterone on the growth and calcification of bones in chickens. They suggested that the effects of (TP) may be due to many factors such as breeds of chickens, lighting schedules, route and dosage of administration of the hormone. Lin and Hsu, (2003) reported positive in intact relationship between body weight and shank length. They also, reported that the androgenic effects on secondary sexual characteristics are stronger than the anabolic growth effects. They added that, shank length $(\mathrm{mm})$ at 28 week of age was significantly reduced.

\section{Effect of in ovo injection of testosterone on plasma biochemical parameters}

Table (3) presents that plasma concentration of total protein, albumin and globulin were different significantly in injected groups compared with control. Testosterone injection caused a significant increase in plasma protein levels and it was dose dependent. Plasma concentration of calcium and phosphorus were increased in testosterone injected groups compared with control (Table 4). While the activity of alkaline phosphatase enzyme was decreased with testosterone injection. Alkaline phosphatase (ALP) is an enzyme that produce by the liver and the highest concentration of ALP is present in cell comprise bone and liver cell, any liver disease or bone disorders cause an increase in plasma levels of ALP. So, in ovo injection of testosterone had improved the bone status and liver function and was related to decrease in ALP levels. Lin and Hsu, (2003) found that alkaline phosphatase activity at 28 week of age was significantly reduced. They added that, Plasma testosterone was high in intact birds. Table (5) showed the plasma cholesterol concentrations. It was noted that the highest cholesterol level was recorded for control group (164.6 mg/dL), while the lowest level was recorded for T1 (149.3 mg/dL). Testosterone injection caused a significant decrease in cholesterol levels .Similar trends were obtained for the values of triglycerides, but the lowest values were for T2. Connor et al (1969) reported that the serum lipid of chick was fractional by their layer included; phospholipid, cholesterol, fatty acids, triglycerides (95\%) was cholesterol. Previous studies have concluded that almost all of the cholesterol contained in newly hatched chick originates from the egg yolk since the specific activities of cholesterol from intestine, liver, heart, serum, carcass and whole chick were 95-98\% of the specific activity of yolk sac, The rate of intestinal lipid absorption was higher at hatchery and did not change post hatch. We have attributed the yolk lipid reach the intestine and are digested before hatch. Some previous studies have shown that chick at hatch have suboptimal absorption of lipids from the diet. Thus close to hatch, the lipoprotein of yolk or yolk endodermal origin is apparently responsible for much of the lipid transport. However, these lipoproteins are metabolized during the immediate post-hatch period and hence circulating LDL and HDL concentrations decrease post-hatch, Sklan, (2003).

Several authors concluded that cholesterol is biosynthesized in the chick embryo during incubation. These studies suggested that cholesterol was transferred intact from the blood of the hen through the ovarian membrane into the egg yolk and then transferred through embryonic membrane into the chick blood and tissues. The high concentration of cholesterol probably cause by the direct transference of cholesterol from the cholesterol-rich egg yolk, Connor et al (1969). After hatching the chick develops its own mechanisms for cholesterol synthesis and excretion and is not being continually challenged with a cholesterol-rich diet from egg yolk. Also, Connor et al (1969) suggested that cholesterol was transferred intact from the blood of the hen through the ovarian membrane into egg 
Table 2. Effect of in ovo injection with Testosterone propionate on body and shank length of Dokki- 4 broiler chicks in experimental groups

\begin{tabular}{|c|c|c|c|c|c|}
\hline \multirow{2}{*}{ Traits } & \multirow{2}{*}{ Sex } & \multirow{2}{*}{ Control } & \multicolumn{2}{|c|}{ Testosterone } & Overall \\
\cline { 4 - 5 } & & $\mathbf{T 1}$ & $\mathbf{T 2}$ & mean \\
& & & $\mathbf{2 5 \mu g}$ & $\mathbf{1 0 0} \boldsymbol{\mu g}$ & \\
\hline \multirow{3}{*}{ Chick Length.cm } & $\mathrm{M}$ & 17.35 & 17.50 & 17.57 & $17.47 \mathrm{a}$ \\
& $\mathrm{F}$ & 17.05 & 17.45 & 17.17 & $17.22 \mathrm{~b}$ \\
& Overall & $17.20 \mathrm{~b}$ & $17.47 \mathrm{a}$ & $17.37 \mathrm{ab}$ & 17.34 \\
\hline \multirow{3}{*}{ Shank Length.mm } & $\mathrm{M}$ & 25.35 & 26.07 & 26.11 & $25.84 \mathrm{a}$ \\
& $\mathrm{F}$ & 24.80 & 26.17 & 25.25 & $25.55 \mathrm{~b}$ \\
& Overall & $25.08 \mathrm{~b}$ & $26.12 \mathrm{a}$ & $25.68 \mathrm{a}$ & 25.69 \\
\hline
\end{tabular}

\begin{tabular}{|c|l|l|l|}
\hline Traits & TRT & SEX & TRT ${ }^{*}$ SEX \\
Chick Length prob. & 0.05 & 0.05 & 0.09 \\
Sign. & $*$ & $*$ & NS \\
Shank Length prob. & 0.05 & 0.03 & 0.90 \\
Sign. & $*$ & $*$ & NS \\
\hline
\end{tabular}

$\mathrm{F}=$ Female. $\mathrm{M}=$ Male

a, b, c; means in the same Column within each classification bearing different letters are Significantly different. sig. $=$ Significance $. N S=$ non-significant, ${ }^{*}=(P \leq 0.05),{ }^{* *}=(P \leq 0.01)$.

Table 3. Effect of in ovo injection with Testosterone propionate on Plasma protein of Dokki-4 broiler chicks in experimental groups

\begin{tabular}{|c|c|c|c|c|c|c|}
\hline \multirow{3}{*}{ Traits } & \multicolumn{3}{|c|}{ Treatments } & \multirow{3}{*}{ SEM } & \multirow{3}{*}{$P$ value } & \multirow{3}{*}{ Sig. } \\
\hline & \multirow[b]{2}{*}{ Control } & \multicolumn{2}{|c|}{ Testosterone } & & & \\
\hline & & $\begin{array}{c}\text { T1 } \\
25 \mu \mathrm{g}\end{array}$ & $\begin{array}{c}\mathrm{T} 2 \\
100 \mu \mathrm{g}\end{array}$ & & & \\
\hline T-Protein(g/dl) & $2.96^{b}$ & $3.28^{\mathrm{ab}}$ & $4.68^{a}$ & 0.109 & 0.0001 & ** \\
\hline Albumin(g/dl) & $1.38^{\mathrm{b}}$ & $1.50^{\mathrm{ab}}$ & $2.23^{\mathrm{a}}$ & 0.04 & 0.0001 & ** \\
\hline Globulin(g/dl) & $1.58^{\mathrm{b}}$ & $1.78^{\mathrm{ab}}$ & $2.45^{\mathrm{a}}$ & 0.07 & 0.0001 & $\star *$ \\
\hline
\end{tabular}

Table 4. Effect of in ovo injection with Testosterone propionate on $\mathrm{Ca}, \mathrm{P}$ and Alkaline phosphatase of Dokki-4 broiler chicks in experimental groups

\begin{tabular}{|c|c|c|c|c|c|c|}
\hline \multirow{3}{*}{ Traits } & \multicolumn{3}{|c|}{ Treatments } & \multirow{3}{*}{ SEM } & \multirow{3}{*}{$P$ value } & \multirow{3}{*}{ Sig. } \\
\hline & \multirow[b]{2}{*}{ Control } & \multicolumn{2}{|c|}{ Testosterone } & & & \\
\hline & & $\begin{array}{c}\text { T1 } \\
25 \mu \mathrm{g}\end{array}$ & $\begin{array}{c}\text { T2 } \\
100 \mu \mathrm{g}\end{array}$ & & & \\
\hline $\mathrm{Ca}(\mathrm{mg} / \mathrm{dl})$ & $10.53^{b}$ & $11.00^{\mathrm{a}}$ & $10.99^{a}$ & 0.27 & 0.001 & ** \\
\hline$P(m g / d l)$ & $4.75^{\mathrm{b}}$ & $5.02^{\mathrm{a}}$ & $4.89^{\mathrm{ab}}$ & 0.44 & 0.001 & ** \\
\hline $\operatorname{ALP}(\mathrm{U} / \mathrm{dl})$ & $6.2^{\mathrm{a}}$ & $5.44^{\mathrm{ab}}$ & $4.17^{b}$ & 6.00 & 0.05 & * \\
\hline
\end{tabular}

SEM=Standard error of means.

a, b, c... means in the same Column within each classification bearing different letters are significantly different. sig. $=$ Significance

NS=non-significant, ${ }^{*}=(P \leq 0.05),{ }^{* *}=(P \leq 0.01)$ 
Table 5. Effect of in ovo injection with Testosterone propionate on some lipid Profile of Dokki-4 broiler chicks in experimental groups

\begin{tabular}{|c|c|c|c|c|c|c|}
\hline \multirow[b]{3}{*}{ Traits } & \multicolumn{3}{|c|}{ Treatments } & \multirow{3}{*}{ SEM } & \multirow{3}{*}{$P$ value } & \multirow{3}{*}{ Sig. } \\
\hline & \multirow[b]{2}{*}{ Control } & \multicolumn{2}{|c|}{ Testosterone } & & & \\
\hline & & $\begin{array}{c}\text { T1 } \\
25 \mu \mathrm{g}\end{array}$ & $\begin{array}{c}\mathrm{T} 2 \\
100 \mu \mathrm{g}\end{array}$ & & & \\
\hline Cholesterol(mg/dl) & $164.6^{\mathrm{a}}$ & $149.3^{\mathrm{ab}}$ & $153.6^{\mathrm{ab}}$ & 1.04 & 0.002 & ** \\
\hline Tri-lycerides(mg/dl) & $153.6^{\mathrm{a}}$ & $132.0^{\mathrm{b}}$ & $129.0^{b}$ & 4.55 & 0.002 & ** \\
\hline
\end{tabular}

SEM $=$ Standard error of means.

a, b, c... means in the same Column within each classification bearing different letters are significantly different. sig. $=$ Significance

NS=non-significant, ${ }^{*}=(P \leq 0.05),{ }^{* *}=(P \leq 0.01)$.

yolk and then transferred through embryonic membrane into the chick blood and tissues. Several authors concluded that cholesterol is biosynthesized in the chick embryo during incubator. Thommes and Shulman, (1967) suggested that the developing chick embryo may exert hormonal control via the pituitary-adrenal axis over its lipid metabolism and the transfer of cholesterol from yolk. Lipid metabolism is an important aspect of chick embryonic development .because avian embryos derives over $90 \%$ of the caloric requirement from fatty acid oxidation, Donaldson, (1981). In addition, the embryo requires fatty acids for synthesis of phospholipids for membrane formation and for synthesis of triglycerides for energy storage, Donaldson, (1981).

It could be concluded that TP injection in ovo at $5^{\text {th }}$ day of incubation improved chick weight, chick length and some plasma biochemical parameters of Dokki-4 broiler chicks.

\section{REFERENCES}

Bruggeman V., Van As P. and Decuypere E. 2002. Developmental endocrinology of the reproductive axis in the chicken embryo. Comp. Biochem. Physiol. A: Mol. Integr. Physiol., 131, 839-846.

Burke W.H. and Sharp P.J. 1989 .Sex differences in body weight of chicken embryos. Poultry Sci., 68, 805-810.

Burke W.H., Arbtan K.D. and Snapir N. 1990. The role of Plasma thyroid hormones in the regulation of body weight of Single Comb White Leghorn and broiler embryos. Poultry Sci., 69, 1388-1393.
Burke W.H. 1992. Sex differences in incubation length and hatching weights of broiler chicks. Poultry Sci., 71, 1933-1938.

Connor W.E., Johnston R., Lin D.S. 1969. Metabolism of cholesterol in the tissues and blood of the chick embryo .J. Lipid Res.,10, 388-394.

Donaldson W. E., 1981.Lipid metabolism in chick embryos. Poultry Sci. 60, 1964-1970.

Doumas B.T. and Biggs H.G. 1972. Determination of serum globulin. In: standard method of clinical chemistry. Vol. 7, Copper, G.R. (ed.). New York, USA, Academic Press. 175p.

Duncan D.B. 1955. Multiple ranges and Multiple Ftest Biometrics.11, 1-42.

Fennell M.J. and Scanes C.G. 1992. Inhibition of growth in chickens by testosterone, 5adihydrotestosterone, and 19-nortestosterone. Poultry Sci., 71, 357-366.

Hamburger V. and Hamilton H.L. 1951. A series of normal stages in the development of the chick embryo. J. Morphol., 88, 49-92.

Hamburger V. and Hamilton H.L. 1992. A series of normal stages in the development of the chick embryo. Dev. Dyn., 195, 231-272.

Henry R.J. 1974. Clinical chemistry, principles and technics. Harper and Row, New York, NY, USA, 407p.

Henry M.H. and Burke W.H. 1998. Sexual dimorphism in broiler chick embryos and embryonic muscle development in late incubation. Poultry Sci., 77, 728-736.

Henry M.H. and Burke W.H. 1999. The effects of in ovo administration of testosterone and an anti-androgen on growth of chick embryos and embryonic muscle characteristics. Poultry Sci., 78, 1006-1013. 
Lin C.R. and Hsu J.C. 2003. Comparison of some selected growth, physiological and bone characteristics of capon, slip and interact birds in Taiwan country chicken cockerels. Asianustral. J. Anim. Sci., 16, 50-56.

Major A.T. and Smith C.A. 2016. Sex reversal in birds. Sex. Dev.,10, 288-300.

Moghaddam A.A., Borji M. and Komazani D. 2014. Hatchability rate and embryonic growth of broiler chicks following in ovo injection royal jelly. Br Poult Sci., 55(3), 391-397.

Rath N.C., Huff W.E., Balog J.M. and Bayyari G.R. 1996. Effect of gonadal steroids on bone and other physiological parameters of male broiler chickens. Poultry Sci., 75, 556-562.

Richmond N. 1973. Preparation and properties of cholesterol oxidase from nacardia SP. and its application to enzymatic assay of total cholesterol in serum. Clin. Chem., 19(12),1350-1356.

SAS, 1998. Statistical Analysis System, SAS User's Guide: Statistics Ver.6.04, $4^{\text {th }}$ Ed., SAS Institute. Inc. Cary, NC., USA.

Sklan D. 2003. Fat and Carbohydrate use in post hatch chicks. Poultry Sci., 82, 117-123.
Stein E.A. and Myers G.L. 1995. National cholesterol education program recommendations for triglyceride measurements: Executive summary. Clin. Chem., 41(10), 1421-1426.

Tietz N.W. 1976. Fundamentals of clinical chemistry $2^{\text {nd }}$ Ed. W.B. Saunders Co., Philadelphia., $154 \mathrm{p}$.

Thommes R.C. and Shulman R.W. 1967. Endocrine control of metabolism in the development chick embryo: Blood Cholesterol Gen-Comp. Endocrinol., 8, 54-60.

Vaillant S., Dorizzi M., Pieau C. and RichardMercier N. 2001. Sex reversal and aromatase in chicken. J. Exp. Zool., 290, 727-740.

Vaillant S., Guemene D., Dorizzi M., Pieau C., Richard-Mercier N. and Brillard J.P. 2003. Degree of sex reversal as related to plasma steroid levels in genetic female chickens ( $\mathrm{Gal}$ lus domesticus) treated with Fadrozole. Mol. Reprod. Develop., 65, 420-428.

Whiting T.S. and Pesti G.M. 1983. Effects of the dwarfing gene (dw) on egg weight, chick weight and chick weight egg weight ratio in a commercial broiler strain. Poultry Sci., 62, 2297-2302. 
مجلة اتحاد الجامعات العربية ، للعلوم الزراعية ، جامعة عين شمس ، القاهرة ، مصر مجلد(26)، عدد(2D) ، عدد خاص ، 2367-2359، 2019 ، 2010

Website: http://strategy-plan.asu.edu.eg/AUJASCl/

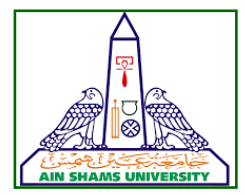

تأثير حقن البيض بالتستوستيرون على الفقس و مكونات البلازما فى دجاج دقى-4

[172]

هناء مصطفى حسين - نعمة الله جمال الدين محمد - فيصل بيومى عبد السلام بدرى - مى فؤاد على

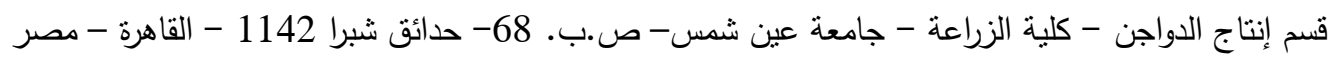

*Corresponding author: faisalbadri@agr.asu.edu.eg

$$
\text { وكاتت أهم النتائج المتحصل عليها كالاتى: }
$$

أنخفضت نسبة الفقس للكتاكيت المحقونة بالهرمون

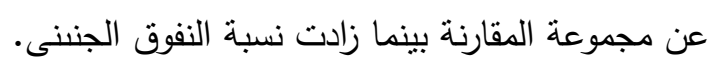

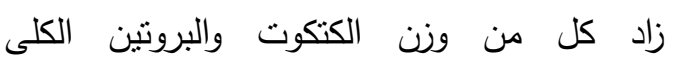

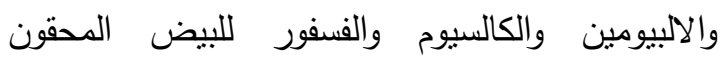

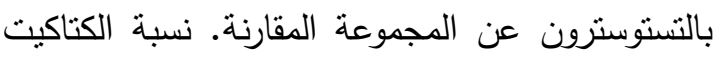

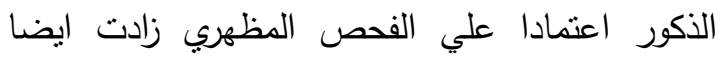
للبيض المحقون بالهرمون عن مجموعة المقارنة .

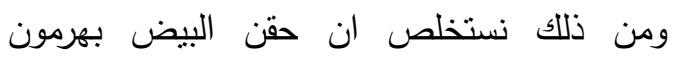
التستوستيرون عند اليوم الخامس من التطور الجنيني يزيد من الصفات المدروسة وتزيد كل من وزن الكنة الكتكوت الجنين وطولة خاصة الذكور عن البيض المقارنة.
أجريت هذه التجربة لدراسة تاثير حقن البيض

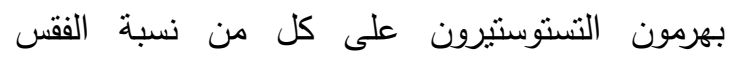

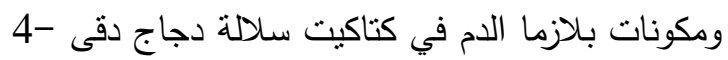

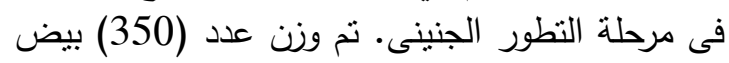

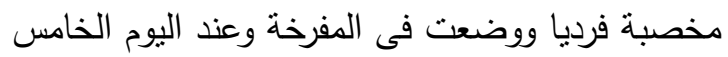

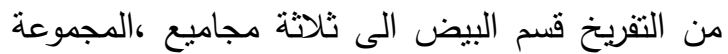

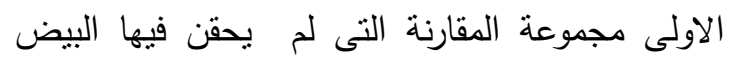
بينما حقنت المجموعة الثانية والثالثة ب25 الثانية و 100

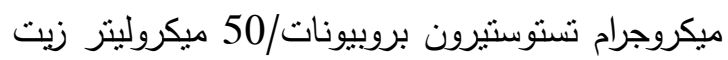

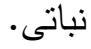

الكلمات الدالة: تستوستيرون بروبيونات، الحقن فى دي البيض، الفقس، نسبة الذكور، دجاج دقى 4 
